\title{
Innovation of microorganism technology and utilization of waste of coconut water for Spur growth of Lettuce (Lactuca sativa $L$ )
}

\author{
Ririen Prihandarini ${ }^{1 *}$, Ellik Murni $^{2}$ \\ 1,2 Faculty of Agriculture, University Widya Gama, Malang, Indonesia
}

\section{Keywords \\ Microorganism \\ Organic farming \\ Lettuce}

Received: 9 October 2017

Accepted: 15 November 2017

Published: 7 February 2018

\begin{abstract}
Lettuce (The current research was conducted to find the nitrogen content of fertilizer from coconut wastewater with microbial L. bulgaricus, L. acidophilus and $S$. thermophilus. The study was prepared based on a Completely Randomized Design with a single factor treatment. The treatments are P1: ZA 1.8 g/polybag Fertilizer, P2: Liquid Wastewater Fermented coconut water $250 \mathrm{ml} / \mathrm{lt}$. water, P3: Fertilizer liquid wastewater of coconut water 500 $\mathrm{ml} / \mathrm{lt}$. water, P4: Fertilizer liquid wastewater of $250 \mathrm{ml}$ fermented coconut/lt. water and R1M solution $10 \mathrm{ml} / \mathrm{lt}$. water and P5: Liquid wastewater of fermented coconut water $500 \mathrm{ml} / \mathrm{lt}$. of water and R1M solution $10 \mathrm{ml} / \mathrm{lt}$. water. Each treatment was repeated as many as 3 replications. The growth observations included leaf area, wet weight, and dry weight of lettuce plant. The results showed that Inorganic fertilizer treatment and treatment of coconut wastewater fertilizer fertilized by L. bulgaricus, L. acidophilus, and S. thermophilus have no significant effect on leaf area formation, wet weight, and dry weight of lettuce plant. Coconut wastewater fertilizer is fermented by L. bulgaricus, L. acidophilus, and S. thermophilus concentration of $250 \mathrm{ml} / \mathrm{lt}$. of water able to spur the growth of lettuce plant. An increase in waste output will accompany increased advancement in the coconut food industry's technologies. The waste of coconut water that is prevalent in the marketplaces emits an odor. Coconut water is an excellent media if it is used for the development of microbes.
\end{abstract}

(C) 2018 The Author(s). Published by TAF Publishing.

\section{INTRODUCTION}

Lettuce (Lactuca Sativa) is grown using chemical/inoganic fertilizers and pesticides. The rate of fertilizer and peticide use tends to increase to obtain maximum results. Excessive use of inorganic fertilizer and pesticide will cause residues on soil and crops that endanger consumers, given the lettuce is consumed a lot of leaves in a fresh state [1].

The availability of inorganic fertilizers is often scarce and the price is relatively expensive. Dependence on the use of inorganic fertilizers can be replaced by the use of organic fertilizers. Organic fertilizers by utilizing waste or waste of disposable agricultural products can be utilized as a source of plant nutrients as fertilizer [2,3].

Increased progress in the technology of the coconut food industry will be followed by increasingly increasing waste output. The waste of coconut water that is much wasted in the markets causes odor. Coconut water is a good medium for the growth of microorganisms and causes pollution if not managed properly [4].

Coconut water waste has been widely used as industrial materials, such as nata de coco and vinegar, but has not been used for cultivation. According to [5], Coconut water contains lactose, protein, nitrogen, phosphorus, and potassium. Nitrogen, phosphorus, and potassium elements can be utilized in coconut water waste that can be utilized as nutrient fulfillment [6]. Coconut also contains growth hor-

mone of plants auxins and cytokinins that have role in the growth of plant cells [7].

The utilization of coconut wastewater for the cultivation of plants must undergo a fermentation process in order

\footnotetext{
${ }^{*}$ Corresponding author: Ririen Prihandarini

†email: ririenuwg@gmail.com
} 
to produce the nutrients available to the plants $[8,9]$. Fermentation of coconut water waste aims to describe the compounds present in the waste. The process of fermentation of coconut water waste is influenced by the existence of microorganisms and their activities $[3,10]$. Microorganisms that have a role in the process of fermentation include Lactobacillus bulgaricus, Lactobacillus acidophilus, and Streptococcus thermophilus [11].

R1M (Refresh Microorganism) is a collection of naturally selected microorganisms, specifically used to help plants in their activities. In R1M, there are 79 species of microorganisms including Bacteria, Fungi, Yeast, and Algae. The number of microorganisms is $1 \mathrm{cc}$ R1M to $1,12 \times 107$, all trained to live together in a medium to be mutually tolerant and mutually helpful [12].

Microbial L. bulgaricus, L. Acidophilus, and S. thermophilus are groups of bacteria that have a role in converting lactose into lactic acid [13]. The existence of microorganisms is supported by environmental conditions that will accelerate the process of fermentation.

Lettuce plant in its growth requires a lot of nitrogen nutrients in the amount of 300-400 kg urea/ha enough for the formation of plant organs [11]. Age of relatively short lettuce plants requires special consideration in the application of fertilizer nutrients in fertilizers in available conditions that can meet the nutrient needs for plants. The liquid waste of fermented coconut water can provide some of the nutrient nitrogen needed in the cultivation of lettuce crops.

\section{A. Aim}

This research was conducted with the aim of:

1. Knowing nitrogen content in fertilizer result of fermentation of wastewater of coconut with innovation of microorganism of L. bulgaricus, L. acidophilus, and S. thermophiles as well as microorganisms in R1M (Refresh Microorganism).

2. Knowing the influence of fertilizer waste of fermented coconut water on growth and yield of lettuce crop.

\section{RESEARCH METHODS}

This research was conducted at Experimental Field of Agricultural Faculty of Widyagama University, Mojolangu Village, Kec. Lowokwaru, KotaMalang. Materials used in the study include green rapid lettuce seeds, polybag bags, coconut liquid wastewater manure, L. bulgarigus bacteria, $L$. acidophillus, $S$. thermophillus, microorganisms in R1M, and urea fertilizer. The tools used include weights, hoes, hand sprayer, measuring cups, and ovens.

The study used a single factor treatment design prepared in a Completely Randomized Design, where each treatment was repeated three times. Kind Treatment consists of:

P1 = Fertilizer ZA1.8 g/polybag

P2 = Fertilizer wastewater of fermented coconut water 250 $\mathrm{ml} / \mathrm{lt}$. of water

P3 = Fertilizer liquid waste of fermented coconut water 500 $\mathrm{ml} / \mathrm{lt}$. of water

P4 = Liquid wastewater of fermented coconut water $250 \mathrm{ml}$ / lt. of water and R1M solution $10 \mathrm{ml} / \mathrm{lt}$. water

P5 = Fertilizer liquid wastewater of coconut water 500 $\mathrm{ml} / \mathrm{lt}$. water and $\mathrm{R} 1 \mathrm{M}$ solution $10 \mathrm{ml} / \mathrm{lt}$. water.

\section{A. Implementation of Research}

1) Fermentation of liquid waste of coconut water: Starter preparation was performed with 0.1 gram of lactic Acid Bacteria Yoghurt (BAL): L. bulgarigus, L. acidophillus, and $S$. thermophillus dissolved in 1 liter of pasteurized milk. Then, it was incubated at $37^{\circ} \mathrm{C} \pm 2^{\circ} \mathrm{C}$ for 24 hours. After incubation, the starter is ready for use in the fermentation of the coconut liquid waste. Fermented waste of coconut water using materials every 10 liters of coconut water waste, given $100 \mathrm{ml}$ suspension of L. bulgarigus bacteria, L. acidophillus, and $S$. thermophillus, was further stirred and ingredients were consumed for 3 days with a sealed container.

2) Planting lettuce crops: Planting media in the form of soil derived from the occupied land were inserted into polybags with a weight of $6 \mathrm{~kg}$ of soil media. Seedling was done on the bed with the media seedlings manure and soil. Plant removal was done on seeds 3 weeks after planting. Seed planting was selected from uniform seeds with healthy appearance. Each planting hole was planted with one seedling with a distance of polybag $20 \mathrm{~cm} \times 30 \mathrm{~cm}$.

Fertilization is done in accordance with the treatment. The urea fertilizer treatment was administered twice after planting. The treatment of liquid fermented coconut water fertilizer was given once every week as per treatment and each treatment was $200 \mathrm{ml} /$ polybag.

Maintenance includes water treatment, weeding, and control of pests and diseases. Watering was given in accordance with the conditions, where the planting media were in dry conditions by splashing on the surface of the media.

Weeding was done to control the growth of weeds that grow, and was done every once a week for controlling pests and diseases by spraying plants using organic pesticides.

Harvesting of lettuce was done by removing the crop at harvest time and its roots. Observation of growth of lettuce plants dilaukan at age 10 days after planting until harvest (30 days after planting) with interval observation of every 10 days which include: 
1. The area of the leaf, as measured from the leaf that has opened perfectly. Measurement of leaf area using gravimetric method.

2. The fresh weight of the plant, as measured by the total weight of the plant. 3. The dry weight of the plant, as measured by weighing the dry weight of the plant after being stirred at $70{ }^{\circ} \mathrm{C}$ for 24 hours/until it weighs constant.

The quality of wastewater of fermented coconut water was analyzed by total $\mathrm{N}$ content as supporting data.
The data were analyzed statistically with the analysis of variance and if obtained, the results had a significant effect continued with the mean test with $\mathrm{BNJ}$ test $(p=0.05)$.

\section{RESULTS AND DISCUSSION}

\section{A. Results}

The result of nitrogen content analysis on soil treated with P1 to P5 was not significantly different. The effect of treatment on soil nitrogen content by treatment and planted Lettuce can be seen in Figure 1 below.

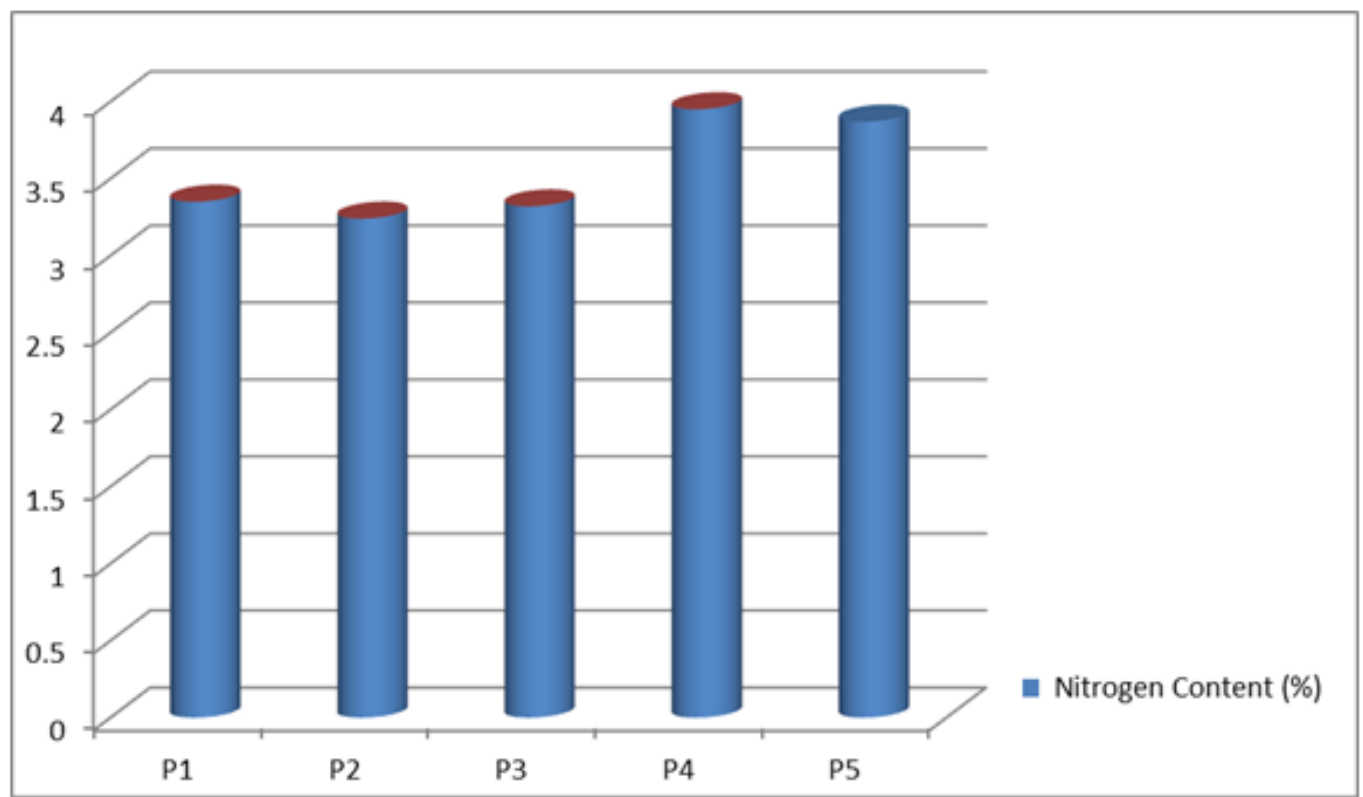

Fig. 1. Effect of treatment on soil nitrogen

The result of observation analysis of leaf lettuce variety showed that the treatment showed no significant effect on various ages of observation. The effect of treatment on the formation of leaf area of lettuce at age 10, 20, and 30 days showed no significant effect. The results of observed growth of leaf lettuce formation are presented in Table 1.

TABLE 1

AVERAGE LEAVES OF PLANT LETTUCE LEAVES PER PLANT $\left(\mathrm{CM}^{2}\right)$ AT VARIOUS AGES OF OBSERVATION

\begin{tabular}{lccc}
\hline \hline Treatment & \multicolumn{3}{c}{ Age (day) } \\
\cline { 2 - 4 } & 10 & 20 & 30 \\
\hline P1 & 24.4927 & 407.5436 & 1097.3934 \\
P2 & 22.0545 & 431.4128 & 1250.9550 \\
P3 & 16.1668 & 414.6160 & 1079.4234 \\
P4 & 27.3187 & 504.1989 & 1206.9830 \\
P5 & 27.6214 & 403.5654 & 1048.0440 \\
BNJ $(\alpha=0.05)$ & tn & tn & tn \\
\hline \hline
\end{tabular}

Description: $\mathrm{tn}=$ no significant difference in $\mathrm{BNJ} 0.05 \%$ test

Increasing the age of the plant increases the leaf area of lettuce. At the age of 10 days on the treatment of P4 and P5, there was formation of larger leaf area but not significantly different from other treatments. At the ages of 20 and 30 days, the formation of leaf area respectively was seen from the largest leaf area of each foreigner on treatments P4, P2, 
P3, P5, and P1 (Figure 1).

showed no significant effect on various ages of observation.

Analysis of variation observation of wet weight of rice plant

TABLE 2

MEAN WEIGHT OF WET LETTUCE PLANT (G) AT VARIOUS AGES OF OBSERVATION

\begin{tabular}{lccc}
\hline \hline \multirow{2}{*}{ Treatment } & \multicolumn{3}{c}{ Age (day) } \\
\cline { 2 - 4 } & 10 & 20 & 30 \\
\hline P1 & 1.3767 & 12.1467 & 68.9000 \\
P2 & 1.6267 & 12.4400 & 81.9233 \\
P3 & 1.6067 & 11.5600 & 71.0233 \\
P4 & 1.8167 & 13.7400 & 82.7633 \\
P5 & 1.3267 & 11.5600 & 71.0867 \\
BNJ $(\alpha=0.05)$ & tn & tn & tn \\
\hline \hline
\end{tabular}

Description: tn $=$ no significant difference in BNJ 0.05\% test

The observations of wet weight growth of lettuce leaf are presented in Table 2. Wet weight of plants at ages 10, 20, and 30 days was not significantly different between treatments. At the age of 10 days, the formation of wet weight of the largest plant to the smallest wet weight respectively was seen on treatments P4, P2, P3, P1, and P5. At age 20, the largest wet weight of the plant to the smallest wet weight was obtained in the treatments of P4, P2, P1, P3, and P5, whereas at the age of 30 days, the wet weight of plant formation to the smallest wet weight respectively was seen in the treatments P4, P2, P5, P3, and P1 and mutually not significantly different between treatments.

The results of various observations of dry weight of lettuce showed no significant effect on ages 10,20 , and 30 days.
The results of observations of dry weight of lettuce plants are presented in Table 3. The dry weight of plants at ages 10,20 , and 30 days was not significantly different between treatments. At the age of 10 days, the largest dry weight formation of the plant to the smallest wet weight was successively treated by P1, P4, P2, P3, and P5. At the age of 20 days, the formation of the wet weight of the largest crops to the smallest dry weight was in the treatments of P4, P2, P5, P1, and P3 and did not differ significantly between treatments. Meanwhile, at age of 30 days, the largest wet weight of the plant to the smallest dry weight was in the treatments of P4, P2, P5, P3, and P1 and did not differ significantly between treatments.

TABLE 3

\begin{tabular}{|c|c|c|c|}
\hline \multirow[t]{2}{*}{ Treatment } & \multicolumn{3}{|c|}{ Age (day) } \\
\hline & 10 & 20 & 30 \\
\hline P1 & 0.5533 & 0.6833 & 3.1733 \\
\hline $\mathrm{P} 2$ & 0.4500 & 0.8667 & 4.3833 \\
\hline P3 & 0.4033 & 0.6667 & 3.3167 \\
\hline $\mathrm{P} 4$ & 0.4767 & 0.8700 & 4.3932 \\
\hline P5 & 0.3500 & 0.8433 & 3.4067 \\
\hline $\operatorname{BNJ}(\alpha=0.05)$ & tn & tn & $\operatorname{tn}$ \\
\hline
\end{tabular}

\section{B. Discussion}

Plant growth shows the interaction results between crop characteristics, environmental conditions, and treatments given to plants. Treatment of fertilizer on the cultivation of lettuce cultivation was an effort to add nutrients needed by plants from outside planting media. Naturally, the nutrient needs of the soil as a medium of the plant are available, but not fully able to meet the needs of the plant. Efforts to provide sufficient nutrient needs can then be done by fertilization.

Fertilization treatment showed no significant effect on the formation of lettuce leaf area at various ages of observa- 
tion (Figure 2). The treatments of P1, P2, P3, P4, and $\mathrm{P} 5$ resulted in the formation of increased lettuce leaf area with increasing plant life. The widespread growth of lettuce leaves showed no significant difference between treatments. The absence of difference in the treatment of leaf area formation was at the beginning of growth until the age of 30 days, presumably during the initial growth of lettuce with ZA inorganic fertilizer treatment, fermented coconut wastewater fertilizer concentration $250 \mathrm{ml} / \mathrm{lt}$. water and $500 \mathrm{ml} / \mathrm{lair}$ and treatment fermented coconut wastewater fertilizer concentration $250 \mathrm{ml} / \mathrm{lt}$. water plus R1M as much as $10 \mathrm{ml} / \mathrm{lt}$. and $500 \mathrm{ml} / \mathrm{lt}$. water plus R1M as much as 10 $\mathrm{ml} / \mathrm{lt}$., because at the time of initial growth until the age of 30 days, it was derived from different fertilizers and supported by optimal environmental conditions for the formation of leaf area. In accordance with the opinion of [14], the growth of one of the plants is determined by the adequacy of nutrients available in the soil. Fertilizers given to lettuce can be organic fertilizers and inorganic fertilizers [15].

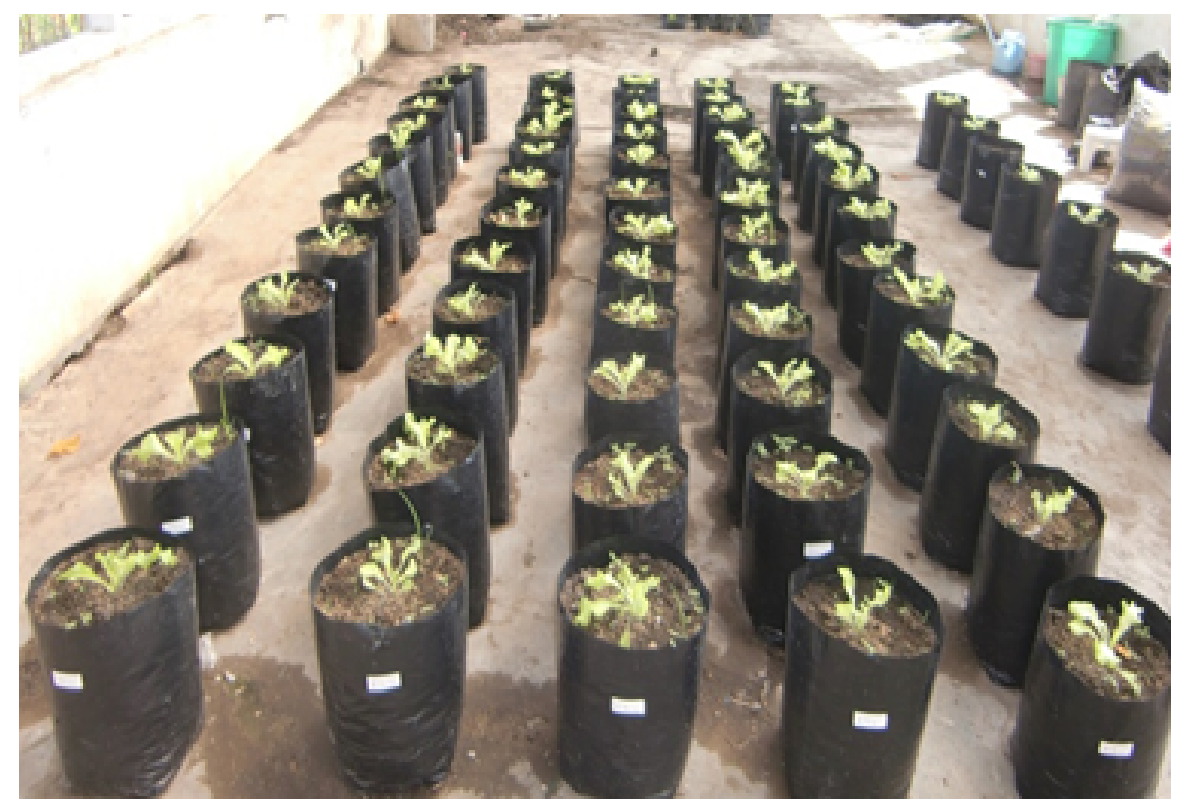

Fig. 2. Lettuce plants aged 10 days after planting

Fertilizer waste of coconut water is fermented by bacteria L. bulgaricus, L. acidophilus, and S. thermophilus able to change the complex compounds in the waste of coconut water. As explained by [13], microbial L. bulgaricus, L. acidophilus, and $S$. thermophilus are groups of bacteria that have a role in converting lactose into lactic acid.

Excess type of ZA inorganic fertilizer is higher nutrient content and quickly available for plants, while the results of laboratory analysis show that the organic fertilizer waste of coconut water is fermented by microbial L. bulgaricus, L. acidophilus, and $S$. thermophilus which contains nitrogen nutrient $0.224 \mathrm{mg} / \mathrm{ml}$. Coconut water contains various nutrients, such as nitrogen, phosphorus, potassium, and growth hormones auxin and cytokinin growth agents, although in small amounts [7]. In accordance with [6], watering coconut wa- ter can increase the growth of patchouli crops. Further research of [5] shows that the use of coconut water is able to spur the multiplication of the formation of temulawak shoots.

In the observation of parameter of weight yield and dry weight of plants, the effect of treatment showed no significant difference (Figure 3 and 4). The average wet weight of plants between treatments was not significantly different. Treatment of P1, P2, P3, P4, and P5 had mean wet weight between treatments that was not significantly different. Fig. 2 shows the formation of wet weight of the plant at age of 10 days, where the wet weight of the largest plant to the smallest wet weight respectively is shown on treatments $\mathrm{P} 4$, P2, P3, P1, and P5, with wet weight per plant respectively $1.8167 \mathrm{~g}, 1.6267 \mathrm{~g}, 1.6067 \mathrm{~g}, 1.3767 \mathrm{~g}$, and $1.3267 \mathrm{~g}$. 


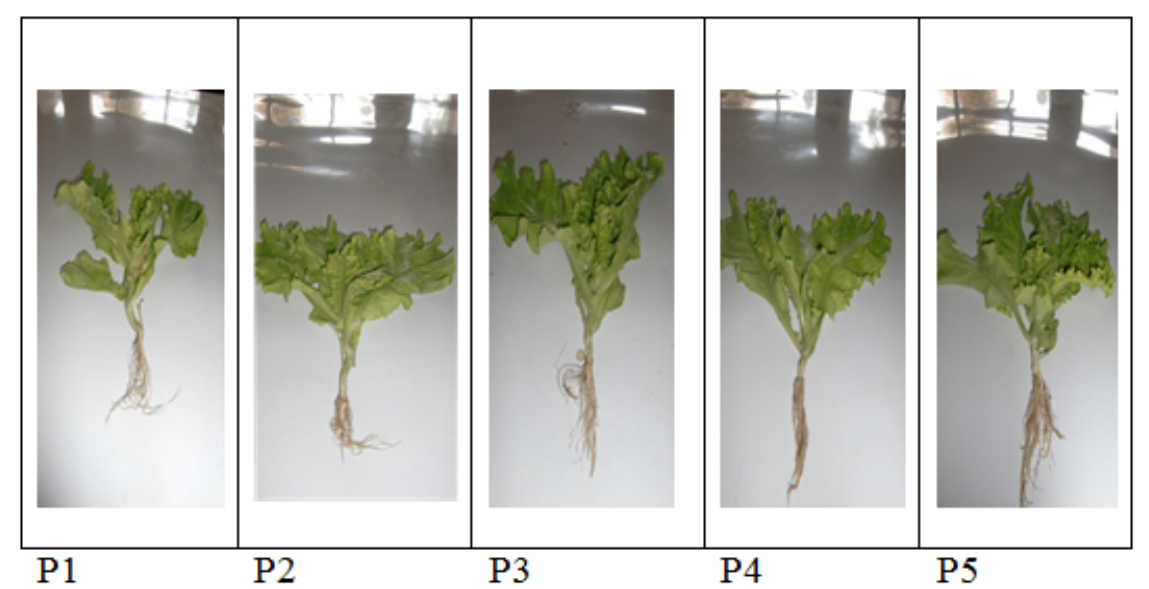

Fig. 3. Lettuce plants at various treatments at 20 days after planting

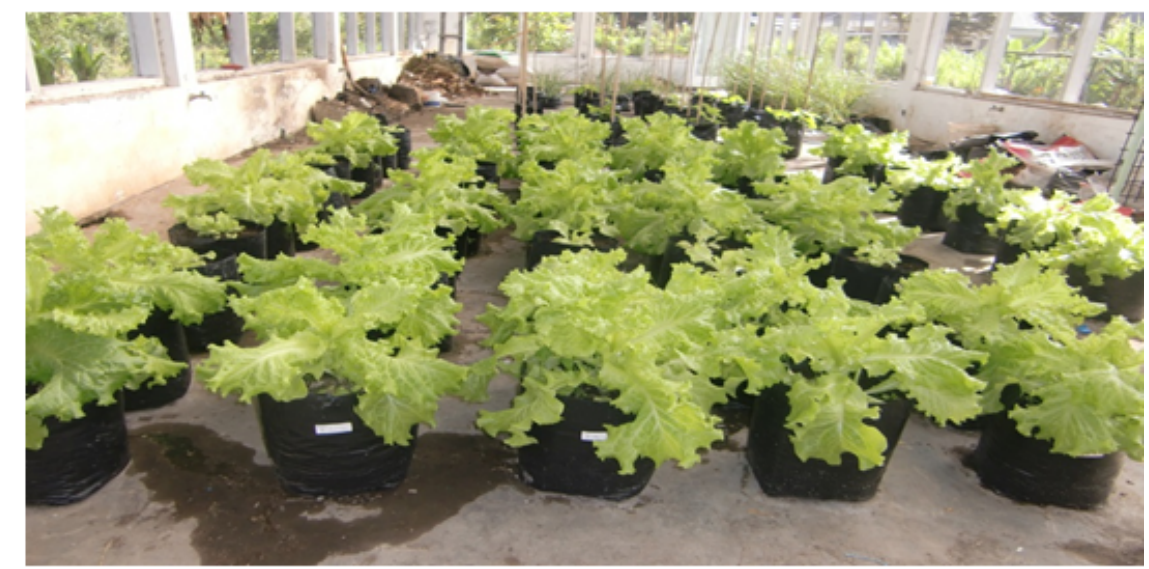

Fig. 4. Lettuce plants at various treatments at 30 days after planting

At 30 days, the highest yield of wetted lettuce to the lower consecutive results was obtained in the treatment of P4, P2, P5, P3, and P1 with wet weight of crops $82.7633 \mathrm{~g}, 81.9233$ $\mathrm{g}$, and $71.0867 \mathrm{~g}, 71.233$, and 68.9000. Different treatments of fertilizers do not affect the results of wet weight of lettuce. It is assumed that the result of wet weight is not significantly different between treatments due to the inorganic fertilizer application of ZA (P1) and the application of coconut wastewater fertilizer by L. bulgaricus, $L$. acidophilus, and S. thermophilus (P2 and P3) and the fermented coconut wastewater treatment by bacteria $L$. bulgaricus, L. acidophilus, and $S$. thermophilus added with R1M solution (P4 and P5), able to provide nutrients as needed by the plants and R1M is a biological fertilizer that is useful to improve the resistance of the soil that is able to loosen soil, healthy soil, and spur growth of plants. Results of wet weight of the plant are also supported by the role of the leaves as the organs that play a role in the process of photosynthesis.

Described by [14], proper fertilization can improve plant growth. Continuing to be mentioned by [16], to obtain good plant growth, the main requirement is the plant should get enough food substances during its growth. [17] explains that plant growth is determined by the amount of nutrients available which are utilized by plants.

The effect of the treatment on the dry weight of the lettuce plant showed no significance. The treatments P1, P2, P3, P4, and P5 had mean dry weight between treatments that were not significantly different. At the age of 30 days, the highest dry weight of lettuce plant yield to the low consecutive results was obtained in the treatments of P4, P2, P5, P3, and P1 with dry weight of $4.4932 \mathrm{~g}, 4.3833 \mathrm{~g}$ and $3.4067 \mathrm{~g}$, $3.3167 \mathrm{~g}$ and $3.1733 \mathrm{~g}$, respectively. Giving different kinds of fertilizers does not affect the dry weight of the lettuce plant. It is suspected that the results of dry weight of plants are not significantly different between treatments, because the treatment of different fertilizers can provide nutrients and be utilized by plants in the formation of plant biomass. Growth of leaf area formation is able to optimize metabolism process of plant photosynthesis and nutrient uptake in the kind of fertilizer treatment given. Nutrient translocation increases as the formation of more ATPs is im- 
portant for transferring assimilation results into the phloem network. Further, assimilated results from the process of photosynthesis in the form of biomass are transferred to all parts of the plant, such as roots, stems, and leaves that spur the growth of lettuce plants.

Explained by [14], growth can run smoothly and positively influences wet weight and further dry weight of plant is increasing. This is supported by the statement of [18], which explains that crop yields are largely determined by the production of dry matter of total crops of broad unity. The total amount of dry matter produced by plants depends on the effectiveness of photosynthesis by plants, i.e., efficiency and extent of assimilation areas [19].

\section{CONCLUSION}

From the results of research, it can be concluded as follows: 1. Inorganic fertilizer treatment and treatment of coconut wastewater fertilizer fertilized by Lactobacillus bulgaricus bacteria, Lactobacillus acidophilus, and Streptococcus thermophilus have no significant effect on nitrogen content, leaf area formation, wet weight, and dry weight of lettuce plant. 2. Fertilizers of coconut wastewater fermented by Lactobacillus bulgaricus bacteria, Lactobacillus acidophilus, and Streptococcus thermophilus concentration of $250 \mathrm{ml} / \mathrm{lt}$. of water can spur the growth of lettuce plants.

3. P4 treatment was able to produce leaf area, plant wet weight, and dry weight of lettuce plant higher, but not significantly different from other treatments.

\section{REFERENCES}

[1] A. B. T. Padi, Vegetable Growing Instructions. Yogyakarta, Indonesia: Kanisius, 2017.

[2] R. Narakhetudomsak and T. Tondee, "Rapid chemical oxygen demand analysis by total organic carbon correlation," International Journal of Applied and Physical Sciences, vol. 2, no. 1, pp. 1-6, 2016. doi: 10.20469/ijaps.2.50001-1

[3] M. Yuwono and G. Indrayanto, "Validation of chromatographic methods of analysis," Profiles of Drug Substances, Excipients and Related Methodology, vol. 32, pp. 243-259, 2005.

[4] D. Setyamijaya, Planting Coconut, Cultivating and Processing. Yogyakarta, Indonesia: Kanisius, 1991.

[5] D. Seswita, "Coconut water usage as growing regulatory on multiplikasi shoots of curcuma (curcuma xanthorrhiza, roxb)," Journal of Vitro Cellular \& Developmental Biology, vol. 16, no. 4, pp. 135-140, 2010.

[6] E. M. N. Ningsih, Y. E. S. Nugroho, and T. Sari, "The growth of patchouli cuttings (pogostemon cablin, benth) on various growing media compositions and dosage watering of coconut water waste," Agricultural Journal, vol. 4, no. 1, pp. 37 47, 2010.

[7] D. Yong, M. A. Toleman, C. G. Giske, H. S. Cho, K. Sundman, K. Lee, and T. R. Walsh, "Characterization of a new metallo- $\beta$-lactamase gene, blandm-1, and a novel erythromycin esterase gene carried on a unique genetic structure in klebsiella pneumoniae sequence type 14 from India," Antimicrobial Agents and Chemotherapy, vol. 53, no. 12, pp. 5046-5054, 2009. doi: 10.1128/aac.00774-09

[8] Y. H. Indriani, Compost Making Quickly. Jakarta, Indonesia: The Swadaya Spreade, 2001.

[9] N. Mahmad, R. M. Taha, N. Rawi, and S. Mohajer, "The effects of picloram and 2, 4-dichlorophenoxyacetic acid on induction of red coloured callus from celosia plumosa, an attractive ornamental plant," Journal of Applied and Physical Sciences, vol. 1, no. 1, pp. 9-12, 2015. doi: 10.20474/-japs1.1.2

[10] A. A. Akinsemolu, "The role of microorganisms in achieving the sustainable development goals," Journal of cleaner production, vol. 182, pp. 139--155, 2018. doi: https://doi.org/10.1016/j.jclepro.2018.02.081

[11] H. Sunaryono, Planting 30 Types of Vegetables. Jakarta, Indonesia: The Swadaya Spreader, 2004.

[12] R. Prihandarini, Role and Function of R1M Microorganism Technology. Jakarta, Indonesia: Masyarakat Pertanian Organik Indonesia, 2003.

[13] M. Tombe and H. Sipayung, Organized Farming with Biofob Technology. Yogyakarta, Indonesia: Lily Publisher, 2010.

[14] P. R. Goldsworthy and F. N. M., Tropical Plant Physiology. Yogyakarta, Indonesia: Gajah Mada University Press, 1996.

[15] T. Simarmata, Integrated Rice-Based Rice Intensification Technology to Multiply Rice Production and Accelerate Achievement of Food Sovereignty in Indonesia. Bandung, Indonesia: Universitas Pajajaran Press, 2008.

[16] F. P. Gardner, R. B. Pearce, R. L. Mitchell et al., Physiology of Crop Plants. New Dehli, India: Scientific Publishers, 2003.

[17] H. Von Uexküll and T. Fairhurst, Fertilizing for High Yield and Quality. Bern, Switzerland: The Oil Palm IPI, 1991.

[18] R. Hunt, Plant Growth Analysis. London, UK: Institute of Terrestrial Ecology, 1982.

[19] Y. Nuraini and N. S. Adi, "Influence of biological fertilizer and organic material to chemical properties and soil biology as well as growth and plants productioncorn (zea mays, l.)," Habitat, vol. 14, no. 3, pp. 139-145, 2003. 